\title{
Peertechz
}

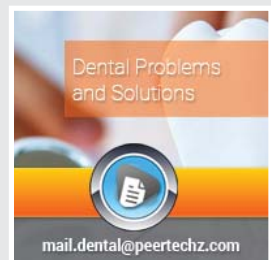

\section{Overdenture: An alternative treatment for oral rehabilitation in patients with early childhood caries}

\section{Márcia Alves Pereira dos Santos' ${ }^{1}$, Liz Helena Moraes Pinheiro², Rafael de Lima Pedro ${ }^{3 *}$, Lívia Azeredo Alves Antunes $^{4}$ and Laura Guimarães Primo ${ }^{5}$}

'DDS, MSD, Colaborate Professor Post-Graduate Program Professional Master of Dental Clinic Faculty of Dentistry of Federal University of Rio de Janeiro and Reference for Sickle Cell Disease in the dental Clinic service at Clementino Fraga Filho Hospital, Federal University of Rio de Janeiro, Brazil ${ }^{2}$ DDS, MSD, PhD student in Postgraduate student of Postgraduate Program in Dentistry, School of Dentistry from the Fluminense Federal University (UFF), Brazil

${ }^{3}$ DDS, MSD, PhD, Dentist of Pediatric Dentistry and Orthodontics Department, School of Dentistry, Federal University of Rio de Janeiro, Rio de Janeiro, Brazil ${ }^{4} \mathrm{DDS}, \mathrm{MSD}, \mathrm{PhD}$, Adjunt Professor of Postgraduate student of Postgraduate Program in Dentistry, School of Dentistry from the Fluminense Federal University (UFF) and Postgraduate Program in Dentistry of Health Institute of Nova Friburgo (PPGO-ISNF) from the Fluminense Federal University (UFF), Brazil

${ }^{5}$ DDS, MSD, PhD, Associate Professor of Pediatric Dentistry and Orthodontics Department, School of Dentistry, Federal University of Rio de Janeiro, Rio de Janeiro, Brazil
Received: 18 February, 2021

Accepted: 27 February, 2021

Published: 01 March, 2021

*Corresponding author: Rafael de Lima Pedro, DDS, MSD, PhD, Dentist of Pediatric Dentistry and Orthodontics Department, School of Dentistry, Federal University of Rio de Janeiro, Rio de Janeiro, Brazil, Tel: +55021970260660; E-mail: drpedrorafael@gmail.com; rafaelpedroufrj@gmail.com

Keywords: Child; Oral rehabilitation; Early childhood caries; Pediatric dentistry

https://www.peertechz.com

\section{Check for updates}

\section{Abstract \\ Oral rehabilitation in child is an odontopediatric challenge once the restorative treatament needs to be done in quick procedures and few visits for maintain cooperative child behaviour. With these objectives in mind, the present report describes an oral rehabilitation using fixed prosthesis (overdenture) in a 3-year-old boy who had early childhood caries and whose dental roots had been endodontically treated. The use of this device is a good aesthetic and functional solution for early teeth lost. Thus, this treatment approach allowed a harmonic dental maintenance in relation to other structures of the stomatognathic system, thus supporting the maxillary development and guiding the eruption of the permanent teeth, in addition to increasing patient and family satisfaction.}

\section{Introduction}

Maintenance of deciduous teeth provides harmonious relationship with other structures of the stomatognathic system, which are important to improve functions such as mastication, deglutition, and phonation [1]. In an addition, it serves to stimulate maxillary development, keeps the antagonists at the occlusal plane, and functions as an eruption guide for the succeeding permanent teeth $[1,2]$.

The loss of anterior teeth may occur in young children between the ages of 6 and 36 months as a result of trauma or 
early childhood caries [3,4]. In this sense, the early loss of these teeth can result in aesthetic and functional problems, delay the eruption of permanent teeth, and promote harmful habits such as lingual interposition and atypical phonation and deglutition $[2,4,5]$. Therefore, the severity of the dental decay, which in most cases may result in extraction, cause dissatisfaction among the parents and may lead to psychosocial problems in their children [2,6-8].

Furthermore, the tooth is the best way of preserving space [1-4]. Cases of extensive decay is a challenge for odontopediatrics, particularly when functional, emotional and aesthetic aspects regarding the anterior teeth are involved [5].

The necessity to reestablish the integrity of deciduous teeth until its physiological exfoliation is the one objective of pediatric dentistry and can be performed by several techniques, among them we can cite restorations using composites resin directly or indirectly [9], celluloid crowns [5] and biological restoration with natural tooth [10-13]. In cases of extensive coronal damage requiring endodontic treatment, intracanal reinforcements (e.g. stainless steel prefabricated posts, composite posts, glass staple fibres posts and biological posts) previously prepared for both supporting forces and providing material retention can be used $[9,14,15]$. Such options need the child's co-operation and long sessions for oral rehabilitation, which must be performed under local anaesthesia and rubber dam placement that could lead to long appointment sessions.

In odontopediatric the appointment duration is very important for maintaing cooperative child behaviour, since time is a crucial factor for performing a successful treatment and promoting the development of a cooperador patient. Therefore, this study aims to present a technique of oral reabilitation for anterior teeth acommeted by early childhood caries by using a fixed appliance (overdenture for children).

\section{Case report}

A Black-African Brazilian boy, 3 years old was attended at the pediatric dentistry clinic of a public graduate institution presenting caries on the upper incisors teeth, which was the main complaint.

During anamnese it was found no changes regarding family or individual history during anamnesis. The mother reported that the child was breast-fed and the oral hygiene was carried out 3 times per day (including one before sleeping). But spite of that there was gingival bleeding during tooth-brushing. On the extra-oral examination, it was observed that the patient had a face characterised by buccal respirator and mandibular projection.

The tissues presented no changes during the intraoral examination, except the lingual interposition and ankyloglossia, which was accounted for the atypical phonation and deglutition.

By considering the occlusal pattern, it was observed a complete deciduous dentition with type I arch, mesial molar relationship at both sides, vestibularization of lower incisors, and presence of open-bite.

The patient had presence of biofilm, high caries activity, extensive coronal destruction involving the 4 upper incisors, and pulpar involvement, which was confirmed by radiographic examination (Figure 1).

At first, the patient's oral condition was improved the adequacy and orienting the parents, that is, breast-feeding should be stopped and hygiene instructions had been recommended. The initial treatment interventions were useful for managing the patient's behaviour as he did not co-operate and was somewhat resistant.

Endodontic therapy was the intervention of choice for teeth $51,52,61$, and 62 . It was performed during two sessions, that is, two teeth by session (Figure $2 \mathrm{~A}$ ). After verifying the success of the pulpar therapy (Figure $2 \mathrm{~B}$ ), the roots were totaly filled and a fixed prosthetic appliance was placed upon them in order to maintain space and aesthetics. The other teeth received the necessary treatments.

The prosthetic rehabilitation management involved one session and consisted in modelling dental casts in order to adapt bands to the second upper deciduous molars so that an arch contouring the whole palate could be welded on the bands. On the anterior part of the arch, where the crowns were absent, a metallic mesh was made and upon it the teeth were acrylized (Figure 3).

Cementation was carried out one week after. Following the oral rehabilitation (Figure $4 \mathrm{~A}, 4 \mathrm{~B}$ ), the parents seemed to be very satisfied with the results and were instructed about

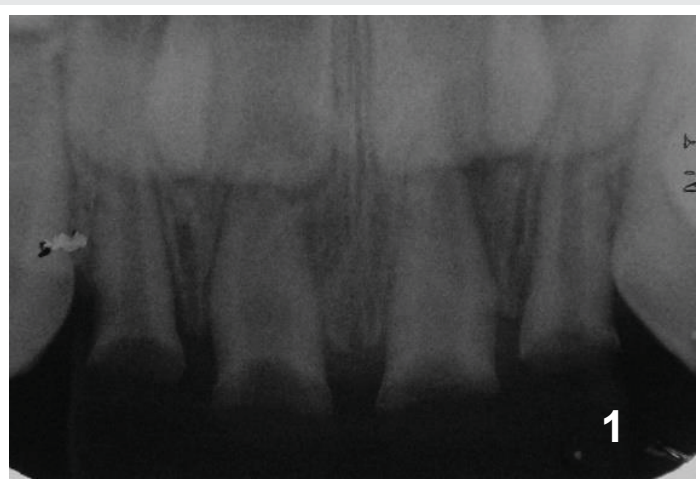

Figure 1: Anterior teeth initial periapical radiograph.
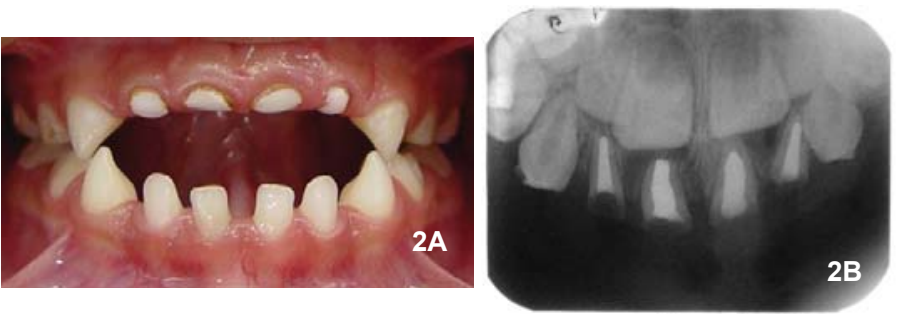

Figure 2: Aspect after endodontic therapy. A: Selament of treated teeth with guttapercha and glass ionomer cement. B: Periapical radiograph with condition to proposed treatment. 
keeping the child's oral hygiene by using unituff tooth-brush and mouth-rising solutions. From that moment, the patient could be referred to a speech therapist for correcting his tongue posture and the need for frenectomy was confirmed and performed subsequently.

The patient returned for follow-up every 3 months in order to have the appliance removed and cleaned as well as to observe the periodontal and the remaining roots. After 1 year of followup it was found that the prosthesis maintained functionally the space left by the absent crowns (Figure 5A,5B).

\section{Discussion}

Authors like Clinchand Healey [16] and McDonald [17] state that those cases involving early loss of anterior deciduous teeth not always need the placement of space maintainers, since each case should be carefully evaluated. However, Moyers [15] believes that the loss of anterior deciduous teeth before the age of 4 years can result in space loss. According to Baume [16], the use of fixed appliances is correctly indicated for children older than 3 years because no changes in the sagittal and transversal dimensions of the dental arches occur, except when they are subject to inadequate environmental influence.

Therefore, based on the age of the patient at the beginning

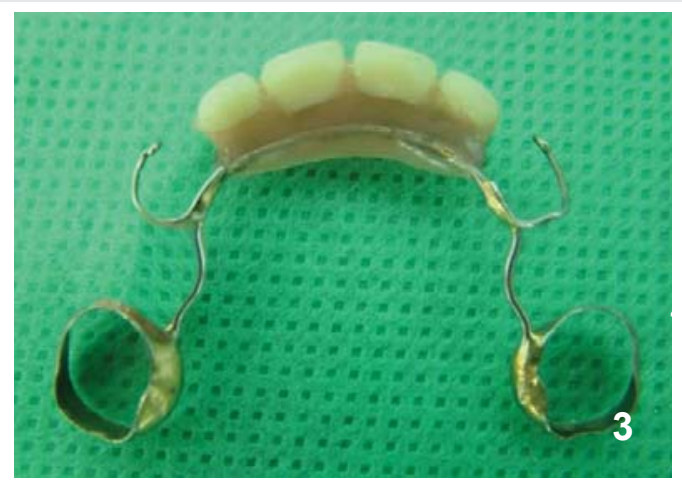

Figure 3: Protetic prosthesis.

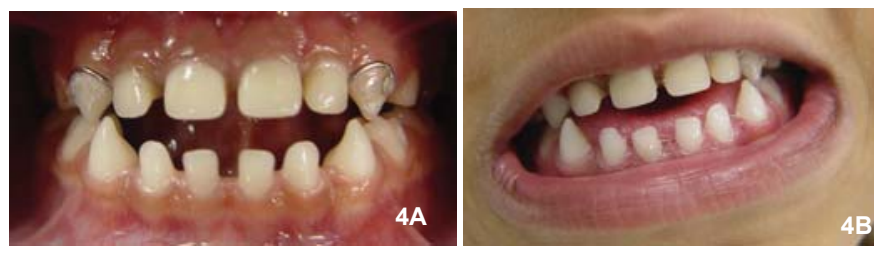

Figure 4A,B: Result imediatly after cementation.
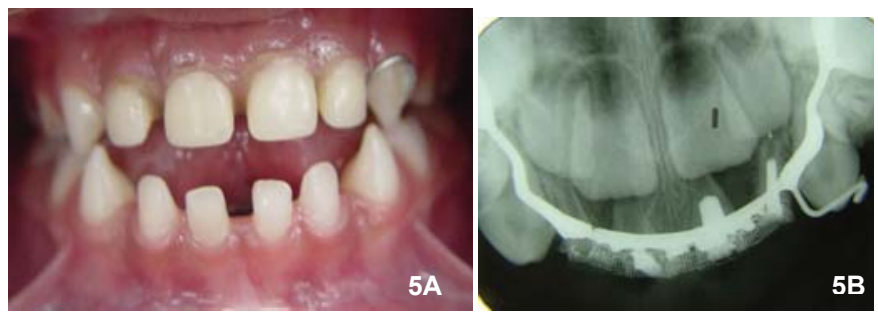

Figure 5A,B: After 1 year of follow-up A: Prosthesis maintained functionally the space left by the absent crowns. B: periapical radiograph. of the treatment $[18,19]$ and aimed to preserve those dental roots, wicth were suitable for endodontic treatment, in order to stimulate maxillary growth and development, the prosthetic appliance was radiographically indicated. Such a condition was kept following treatment and the teeth were found to be satisfactorily filled [20] with no clinical and radiographic changes [21].

In addition to these factors, the treatment indication for the present report was based on the impossibility of restoring the teeth conventionally because of the lack of dental support. Also, as the patient was a young child the treatment had to be of shorter duration and more basic due to the child's uncooperative behaviour. Therefore, this was the treatment approach of choice, since the overdenture principle [22] postulates the making of complete or partial removable appliance to be placed upon the remaining roots or retained teeth in order to improve the prosthesis support or delay the bone resorption. Finally, the use of overdenture also guides the permanent teeth during eruption [22].

Although the removable appliance has disadvantages if used in uncooperative children $[6,23]$, such a technique can employ a fixed space maintainer. Among the treatment options available for partial loss of anterior deciduous teeth, this approach has important advantages such as greater retention, lesser tissue damage, less dependence on the patient's co-operation, and greater adequacy for longer periods of maintenance [23].

Another indication of the overdenture technique would involve non-erupted teeth in children carrying ectodermic dysplasias [24], cases of traumatised central incisors if the roots are to be preserved [25], cases of imperfect dentinogenesis [26], cases of partial anodontia [27] and cases of cleft palate children [28].

Proservation and maintenance should be performed through regular visits in which the same selection criteria (e.g. tooth condition, periodontum, oral hygiene, and patient's motivation) are taken into account, besides the prosthesis' condition [29,30]. According to Ettinger and Qian [31], relapse of periodontal disease and caries are, respectively, the most common causes of treatment failure and loss of permanent teeth under overdentures. Thus, three-monthly visits were established in order to reduce such conditions in the present case study.

Nevertheless, the family participation is crucial for a successful treatment regardless of the type of maintainer appliance used. In the present study the child's parents took part in each phase of the treatment by keeping the prosthesis cleaned and promoting a satisfactory oral condition [32]. According to Rieckman and Elbadraury [33], the use of functional and aesthetic maintainers to substitute the absent incisors is supported in those cases of atypical phonetic development, particularly when the child looses the incisors. Therefore, in the present study an apparatus was made in order to maintain the teeth relationship by serving as a lingual support and guide the eruption of the succeeding permanent teeth. In this way, phonetic and psychological problems could 
also be prevented from occurring [33], which was important for the speech therapy that patient had been submitting to.

A point to highlight is the possibility of devices like this one to increase bacterial plaque retention and consequently increase the possibility of risks of carious injuries [34]. However, when patients and family members are well oriented in terms of intensification of oral hygiene, and regular dentist consultations are held, the benefits outweigh the possible risks of using the device, since rehabilitation, both aesthetic and functional, is closely linked to an improvement in the patient's quality of life [35]. In our case, the patient underwent a previous hygiene adjustment and both he and the family were motivated to use the device, and we realized that this rehabilitation reinforced the concern with oral care.

\section{Conclusion}

The interaction between prosthetic knowledge, space maintenance and basis for functional rehabilitation provided the development of an appliance functionally and aesthetically suitable for the patient's psychosocial growth. In addition, this treatment approach allowed a harmonic dental maintenance in relation to other structures of the stomatognathic system, thus supporting the maxillary development and guiding the eruption of the permanent teeth.

\section{References}

1. Sánchez-González CL, Moreno-Mendez W, Álvarez-Herrera AF, Orozco-Cuanalo L, Vázquez-Pérez LA, et al. (2012) causes of premature loss of deciduous teeth in patients 3 to 10 years at the university clinic of health care Benito Juarez at FES Zaragoza UNAM. Odontol Act 9: 42-50.

2. Bijoor RR, Kohli K (2005) Contemporary space maintenance for the pediatric patient. N Y State Dent J 71: 32-35. Link: http://bit.ly/3kydEcL

3. Vadiaskas G (2008) Case definition, aetiology and risk assessment of early childhood caries (ECC): a revisited review. Eur Arch Paediatr Dent 9: 114-115. Link: http://bit.ly/2MzQxlt

4. Glendor U (2008) Epidemiology of traumatic dental injuries-a 12 year review of the literature. Dent Traumatol 24: 603-611. Link: http://bit.ly/3dZ18S6

5. Chang JZC, Chen PHC, Kuo SC (1999) An appliance to replace prematurely lost maxillary anterior teeth using double stainless steel crowns on abutment teeth. J Clin Pediatr Dent 23: 285-288. Link: http://bit.ly/3bKA8mQ

6. Orsi IA, Farai JFR, Bolsoni I, Freitas AC, Gatti P (1999) The use of resin bonded dentadure to replace primary incisors: Case report. Peaditr Dent 21: 64-66. Link: http://bit.ly/37WXXqi

7. Santana GR, Guaré RO, Rodrigues CRMD, Guedes-Pinto AC (2002) Primary anterior tooth replacement with a fixed prosthesis using a precision connection system: A case report. Quintessence Int 33: 303-308. Link: http://bit.ly/3b35Xb9

8. Carranza F, Garcia Godoy F (1999) Esthetic restoration of primary incisors. Am J Dent 12: 55-58. Link: http://bit.ly/2PIEOId

9. Wanderley MT, Ferreira SLM, Rodrigues CRMD, Rodrigues Filho LE (1999) Primary anterior tooth restoration using posts with macroretentive elements. Quintessence Int 36: 432-436. Link: http://bit.ly/3b0TCnQ

10. Sharaf AA (2002) The application of fiber core posts in restoring badly destroyed incisors. J Clin Pediatr Dent 26: 217-224. Link: http://bit.ly/2MyTC57
11. Upyke J, Sneed WD (2001) Placemente of a performes indirect resin composite shel crow: a case report. Pediatr Dent 23: 243-245.

12. Ramires-Romito ACD, Wanderley MT, Oliveira MDM, Imparato JCP, Corrêa MSNP (2000) Biologic restoration of primary anterior teeth. Quintessence Int 31: 405-411. Link: http://bit.ly/3sCKDPS

13. Barcelos R, Neves AA, Primo L, Souza IP (2003) Biological restorations as an alternative treatment for primary posterior teeth. J Clin Pediatr Dent 27: 305-310. Link: http://bit.ly/3r65MkS

14. Judd PL, Kenny JD, Johnston DH, Yacobi R (1990) Composite resin short-post techinique for primary anterior teeth. J Am Dent Assoc 120: 553-555. Link: http://bit.ly/3r8cbfq

15. Rocha RO, Neves LT, Marotti NR, Wanderley MT, Corrêa MSN (2004) Intracana reintforcement fiber in pediatric dentistry: A case report. Quintessence Int 35 263-268. Link: http://bit.ly/3sGAwtn

16. Clinch LM, Healy MJR (1959) A longitudinal study of the results of premature extraction of deciduous teeth between 3-4 and 13-14 year of age. Dent Pract 9: 104-127. Link: http://bit.ly/2PnWCT1

17. McDonald RE, Avery DR, Dean J (2004) Dentistry for the child and adolescent 8th ed., Ed. Mosby, St. Louis, 784.

18. Moyers RE (1973) Handbook of orthodontics. 3th ed., Ed. Mosby, Chicago.

19. Baume LJ (1950) Physiological tooth migration and its significance for the development of occlusion. The biogenetic course of the deciduous dentition. J Dent Res 29: 123-132. Link: http://bit.ly/3sAX66r

20. Guelmann M, McEachern M, Turner C (2004) Pulpectomies in primary incisors using three delivery systems: an in vitro study. J Clin Pediatr Dent 28: 323-326. Link: http://bit.ly/3q4D8zB

21. Flaitz MC, Barr ES, Hicks MJ (1989) Radiographic evaluation of pulpal therapy for primary anterior teeth. ASDC J Dent Child 56:182-185. Link: http://bit.ly/3b37bDx

22. Lord JL, Teel S (1969) The overdenture. Dent Clin North Am 13: 871-928. Link: http://bit.ly/2NNly5Y

23. Liegeois F, Limme M (1999) Modified bonded bridge space maintainer. J Clin Pediatr Dent 23: 281-284. Link: http://bit.ly/2ZY2i86

24. Bonilla ED, Guerra L, Luna O (1997) Overdenture prosthesis for oral reabilitation of hypohidrotic ectodermal dysplasia: a case report. Quintessense Int 28: 657665. Link: http://bit.ly/3dX51Ho

25. Mackie IC, Quayle AA (1992) Alternative management of a crown root fractured tooth in child. Br Dent J 73: 60-62. Link: http://bit.ly/3aZjAlu

26. Walter LD (1988) The use of overdentures in patients with dentinogenesis imperfecta. J Paediatr Dent 4: 17-25. Link: http://bit.ly/3uGGr3n

27. Esposito SJ, Cowper T (1991) Overdenture in partial anodontia: simple solutions for complex problems. Compedium 12: 172-177. Link: http://bit.ly/3uJAhiP

28. Tejani Z, Kok EC, Manson C, Griffiths B (2005) The use of overentures in children with cleft lip and palate: a report of two cases. J Clin Pediatr Dent 29: 299-306. Link: http://bit.ly/3bLPqaM

29. Qudeimat MA, Fayle SA (1998) The longevity of space maintainers: a retrospective study. Pediatr Dent 20: 267-272. Link: http://bit.ly/37SWOLu

30. Gomes BC, Renner RP (1990) Periodontal considerations of the removale partial overdenture. Dent Clin North Am 34: 653-668. Link: http://bit.ly/207fvJo

31. Ettinger RL, Qian F (2004) Abutment tooth loss in patients with overdentures. J Am Dent Assoc. 135: 739-746. Link: http://bit.ly/3bKBJJm

Citation: Pereira dos Santos MA, Moraes Pinheiro LH, Lima Pedro RD, Alves Antunes LA, Primo LG (2021) Overdenture: An alternative treatment for oral rehabilitation in patients with early childhood caries. J Dent Probl Solut 8(1): 005-009. DOI: https://dx.doi.org/10.17352/2394-8418.000095 
32. Dogan MC, Dogan SK, Kendi E (2005) Complications of pediatric dentadure misuse: a case report. Oral Health Prev Dent 3: 127-130. Link: http://bit.ly/2MxPuCn

33. Riekman GA, Elbradraury HE (1985) Effect of premature loss primary maxillary incisors in speech. Pediatr Dent 7: 119-122. Link: http://bit.ly/3r5alfv
34. Nomura Y, Otsuka R, Wint WY, Okada A, Hasegawa R, et al. (2020) ToothLevel Analysis of Dental Caries in Primary Dentition in Myanmar Children. Int $J$ Environ Res Public Health 17: 7613. Link: http://bit.ly/37Wu9Kw

35. Sacramento PA, de Castilho AR, Frasseto F, Gaviao MB, Nobre-dos-Santos M, et al. (2011) One-year clinical evaluation of oral rehabilitation after the loss of multiple primary teeth. Gen Dent 59: 230-233. Link: http://bit.ly/3pY5kE4

\section{Discover a bigger Impact and Visibility of your article publication with}

\section{Peertechz Publications}

\section{Highlights}

* Signatory publisher of ORCID

* Signatory Publisher of DORA (San Francisco Declaration on Research Assessment)

* Articles archived in worlds' renowned service providers such as Portico, CNKI, AGRIS, TDNet, Base (Bielefeld University Library), CrossRef, Scilit, J-Gate etc.

* Journals indexed in ICMJE, SHERPA/ROMEO, Google Scholar etc.

* OAI-PMH (Open Archives Initiative Protocol for Metadata Harvesting)

* Dedicated Editorial Board for every journa

* Accurate and rapid peer-review process

* Increased citations of published articles through promotions

* Reduced timeline for article publication

Submit your articles and experience a new surge in publication services (https://www.peertechz.com/submission).

Peertechz journals wishes everlasting success in your every endeavours.

Copyright: @ 2021 Pereira dos Santos MA, et al. This is an open-access article distributed under the terms of the Creative Commons Attribution License, which permits unrestricted use, distribution, and reproduction in any medium, provided the original author and source are credited.

Citation: Pereira dos Santos MA, Moraes Pinheiro LH, Lima Pedro RD, Alves Antunes LA, Primo LG (2021) Overdenture: An alternative treatment for oral rehabilitation in patients with early childhood caries. J Dent Probl Solut 8(1): 005-009. DOI: https://dx.doi.org/10.17352/2394-8418.000095 